Circulating concentrations of parathyroid hormone-like peptide in malignancy and hyperparathyroidism. F Bone Miner Res 1990;5:105-13.

12 Budayr AA, Nissenson RA, Klein RF, Pun KK, Clark OH, Dinh Diep BS, et al. Increased serum levels of a parathyroid hormone-like protein in et al. Increased serum levels of a parathyroid hormone-like protein

13 Sato K, Fujii Y, Kasono K, Tsushima T, Shizume K. Production of interleukin- $1 \alpha$ and a parathyroid hormone-like factor by a squamous cell carcinoma of the esophagus (EC-Gl) derived from a patient with hypercalcemia. F Clin Endocrinol Metab 1988;67:592-601.

14 Legha SS, Powell K, Buzdar AU, Blumenschein GR. Tamoxifen-induced hypercalcemia in breast cancer. Cancer 1981;47:2803-6.

15 Danks JA, Ebeling PR, Hayman J, Chou ST, Moseley J, Dunlop J, et al. Parathyroid hormone-related protein: immunohistochemical localisation in cancers and in normal skin. $\mathcal{F}$ Bone Miner Res 1989;4:273-8.

16 Kramer S, Reynolds FH, Castillo M, Valenzuela DM, Thorikay M, Sorvillo $J M$. Immunological identification and distribution of parathyroid hormonelike protein polypeptides in normal and malignant tissues. Endocrinolog 1991;128:1927-37.

17 Ralston SH, Danks JA, Hayman J, Fraser WD, Stewart CS, Martin TJ.
Parathyroid hormone-related protein of malignancy: immunohistochemical and biochemical studies in normocalcaemic and hypercalcaemic patients with cancer. I Clin Pathol 1991;44:472-6.

18 Coleman RE, Fogelman I, Rubens RD. Hypercalcaemia and breast cancer, an increased humoral component in patients with liver metastases. Eur F. Surg Oncol 1988;14:423-8.

19 Southby J, Kissin MW, Danks JA, Hayman JA, Moseley JM, Henderson MA, et al. Immunohistochemical localisation of parathyroid hormone-related protein in human breast cancer. Cancer Res 1990;50:7710-6.

20 Powell GJ, Southby J, Danks JA, Stillwell RG, Hayman JA, Henderson MA, et al. Localisation of parathyroid hormone-related protein in breast cancer metastases: increased incidence in bone compared with other sites. Cancer Res 1991;51:3059-61.

21 Van Holten-Verzantvoort A Th, Bijvoet OLM, Cleton FJ, Hermans J, Kroon HM, Harinck HIJ, et al. Reduced morbidity from skeletal metastases in breast cancer patients during long-term bisphosphonate (APD) treatment. Lancet 1987;ii:983-5.

\title{
Injuries from antipersonnel mines: the experience of the International Committee of the Red Cross
}

\author{
Robin M Coupland, Adriaan Korver
}

Medical Division, the Red Cross, CH1202

Geneva, Switzerland

Robin M Coupland, FRCS, surgeon

Adriaan Korver, MD, medical coordinator

Correspondence to: Mr Coupland.

BMf 1991;303:1509-12

FIG 1-(a) Traumatic amputation of left foot and lower leg caused by $\mid(b)$ buried antipersonnel mine

Design-Retrospective analysis.

Setting-Two hospitals for patients injured in war.

Subjects -757 patients with injuries from antipersonnel mines.

Main outcome measures-Distribution and number of injuries; number of blood transfusions; number of operations; disability.

Results - Pattern 1 injury results from standing on a buried mine. These patients usually sustain traumatic amputation of the foot or leg; they use
International Committee of

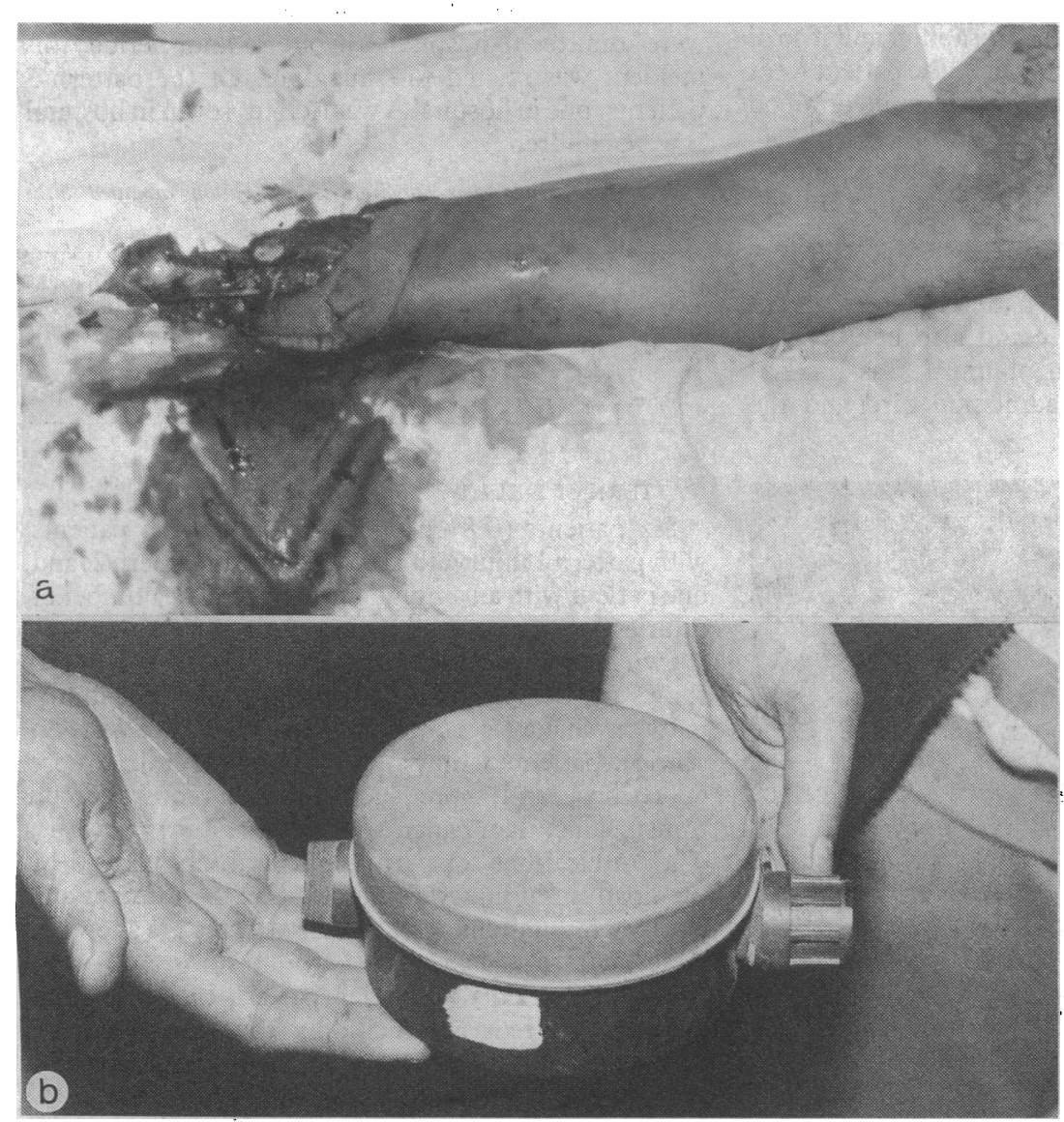

most surgical time and blood and invariably require

Objective-To describe and quantify patterns of injury from antipersonnel mines in terms of distribution of injury, drain on surgical resources, and residual disability.

BMJ VOLUME 303

14 DECEMBER 1991 surgical amputation of one or both lower limbs. Pattern 2 injury is a more random collection of penetrating injuries caused by multiple fragments from a mine triggered near the victim. The lower limb is injured but there is less chance of traumatic amputation or subsequent surgical amputation. Injuries to the head, neck, chest, or abdomen are common. Pattern 3 injury results from handling a mine: the victim sustains severe upper limb injuries with associated face injuries. Eye injuries are common in all groups.

Conclusions-Patients who survive standing on a buried mine have greatest disability. Non-combatants are at risk from these weapons; in developing countries their social and economic prospects after recovery from amputation are poor.

\section{Introduction}

The International Committee of the Red Cross (ICRC) deploys surgical teams for treating victims of war in 13 hospitals in Asia and Africa; these are served by first aid posts near the conflict areas. The teams are recruited from national Red Cross societies for three or six months of service.

Mine warfare is commonly used in developing countries, and antipersonnel mines may injure both combatants and non-combatants during and after a conflict. Surprisingly little attention has been paid to this subject in the medical literature; the medical implications of injury patterns and their severity have not been described.

This study was undertaken after the observation that victims of antipersonnel mines present with recognisable patterns of injury. Each pattern carries its own implication for the surgeon, the blood transfusion service, and patients' long term disability.

Three recognisable patterns of injury are seen in ICRC hospitals. In pattern 1 injury the victims trigger a buried mine by standing on the device. They usually have traumatic amputation of part of the lower limb $b^{1-3}$ with less severe injuries elsewhere; earth and the remains of the foot are blown upwards. Such mines may consist of explosive only or include fragments of metal or plastic. Many are specifically designed to incapacitate by traumatic amputation of all or part of the foot (fig 1). Pattern 2 injury results from a fragment mine being triggered. The pattern of wounding is more random, consisting of multiple fragment wounds (fig 2). Such mines may resemble a grenade and be 

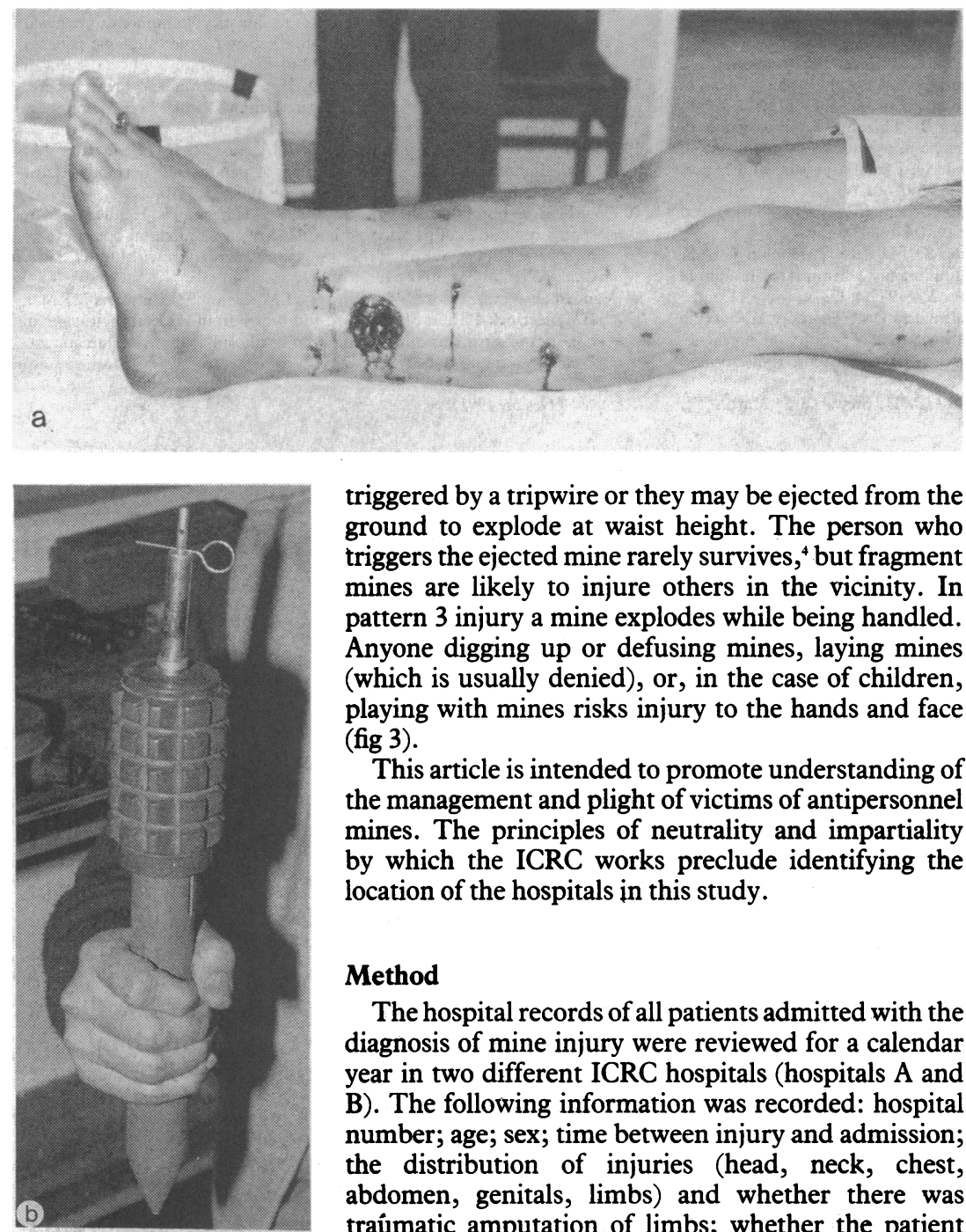

FIG 2-(a) Typical injury of left lower limb from a fragment mine. (b) Disarmed fragment mine, detonator in place; triggered by pulling out pin

triggered by a tripwire or they may be ejected from the ground to explode at waist height. The person who triggers the ejected mine rarely survives, ${ }^{4}$ but fragment mines are likely to injure others in the vicinity. In pattern 3 injury a mine explodes while being handled. Anyone digging up or defusing mines, laying mines (which is usually denied), or, in the case of children, playing with mines risks injury to the hands and face (fig 3).

This article is intended to promote understanding of the management and plight of victims of antipersonnel mines. The principles of neutrality and impartiality by which the ICRC works preclude identifying the location of the hospitals in this study.

\section{Method}

The hospital records of all patients admitted with the diagnosis of mine injury were reviewed for a calendar year in two different ICRC hospitals (hospitals A and B). The following information was recorded: hospital number; age; sex; time between injury and admission; the distribution of injuries (head, neck, chest, abdomen, genitals, limbs) and whether there was traumatic amputation of limbs; whether the patient died; whether the patient underwent surgical amputation; whether there was another disability and if so of what nature; the total number of times the patient went to the operating theatre; the number of units of blood received by the patient.

Each patient was allotted an injury pattern number according to the clinical record. "Stood on a mine," "injured by mine fragments," and "was handling a mine" are typical descriptions of injury patterns and correspond to patients with patterns 1,2 , and 3 respectively. Injury patterns could also be allocated according to the distribution of injuries as marked on the homunculus on the admission card and the
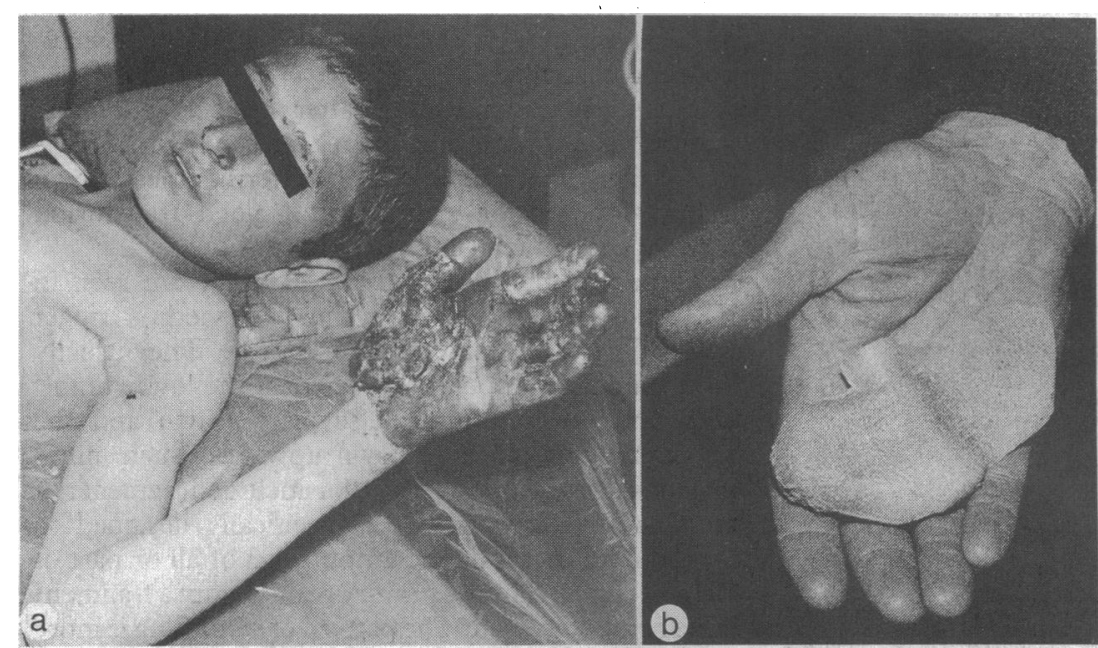

FIG 3-(a) Injuries to left hand and face sustained from picking up (b) mine (without detonator and liquid explosive) dropped from an aircraft operating notes. When there was insufficient information in the records to give a pattern number or the pattern was ambiguous the form was marked with " $N$ " (no pattern); these records were analysed alongside those of other patterns.

Patients who discharged themselves from hospital against medical advice were excluded from the study.

For the purposes of this study non-combatants were defined as women, boys less than 16 years old, and men over 50 years old.

\section{Results}

The records of 757 patients were reviewed, 276 from hospital A and 481 from hospital B. Table I shows the time between injury and admission to the two hospitals table II shows the proportion of patients with each injury pattern admitted to the hospitals. Most patients were admitted 6-24 hours after injury, and mos patients had pattern 2 injuries.

TABLE I - Time between wounding and admission to hospita

\begin{tabular}{lcc}
\hline No of hours & $\begin{array}{c}\text { No of patients in } \\
\text { hospital } A^{\star}\end{array}$ & $\begin{array}{c}\text { No of patients in } \\
\text { hospital B }\end{array}$ \\
\hline$<6$ & 47 & 34 \\
$6-24$ & 130 & 309 \\
2472 & 36 & 87 \\
$>72$ & 39 & 51
\end{tabular}

$\star 24$ Records did not contain this information

TABLE II-Number (percentage) of patients with different injury patterns

\begin{tabular}{lcc}
\hline & $\begin{array}{c}\text { Hospital A } \\
(\mathbf{n}=276)\end{array}$ & $\begin{array}{c}\text { Hospital B } \\
(\mathbf{n}=481)\end{array}$ \\
\hline $\begin{array}{l}\text { Pattern 1 (traumatic amputation of part of lower } \\
\text { limb, less severe injuries elsewhere) }\end{array}$ & $66(24)$ & $135(28)$ \\
$\begin{array}{l}\text { Pattern 2 (multiple fragment wounds) } \\
\text { Pattern 3 (injury to hands and face) }\end{array}$ & $133(48)$ & $236(49)$ \\
Insufficient information or ambiguous pattern & $17(6)$ & $24(5)$ \\
& $60(22)$ & $86(18)$
\end{tabular}

Table III shows the non-combatant population injured by mines. Twelve of the 30 non-combatants were admitted to hospital $\mathrm{A}$ in one 24 hour period; this incident was related to smuggling. Of the pattern 3 patients, one in hospital A was a child; seven in hospital $B$ were children.

TABLE III-Number (percentage) of non-combatants admitted to the hospitals with a diagnosis of mine injury

\begin{tabular}{lcc}
\hline & $\begin{array}{c}\text { Hospital A } \\
(\mathrm{n}=276)\end{array}$ & $\begin{array}{c}\text { Hospital B } \\
(\mathrm{n}=481)\end{array}$ \\
\hline Women & $20(7)$ & $12(2)$ \\
Men $>50$ years & $10(4)$ & $77(16)$ \\
Children $($ aged $<16)$ & $7(3)$ & $55(11)$
\end{tabular}

PATTERN OF INJURY

Six patients $(0.8 \%)$ died in hospital: two patients with pattern 1 injury, three patients with pattern 2 , and $\widetilde{N}$ one patient with an ambiguous pattern. The number of $\mathrm{N}$ injuries sustained in different parts of the body is shown in table IV according to injury pattern. Table $\mathrm{V} o$ shows the demand that patients with different injury $\mathbb{D}$ patterns make on surgical time and the transfusion ?? service: patients with pattern 1 injuries require more $\frac{T}{0}$ operations, and more such patients require blood transfusions, than patients with other injury patterns. The implications for permanent disability carried by $\stackrel{\mathbb{D}}{\stackrel{2}{2}}$ each pattern of injury as indicated by the number and 2 level of amputations and other disabilities are shown in table VI.

For the patients with each pattern the proportion of limbs injured (not including those traumatically $\stackrel{\vec{\partial}}{\partial}$ amputated) that eventually required amputation is given by the formula:

(total number of amputations - number of traumatic 


\begin{tabular}{|c|c|c|c|c|}
\hline & $\begin{array}{c}\text { Injury } \\
\text { pattern 1 } \\
(\mathrm{n}=201)\end{array}$ & $\begin{array}{c}\text { Injury } \\
\text { pattern } 2 \\
(\mathrm{n}=369) \\
\end{array}$ & $\begin{array}{c}\text { Injury } \\
\text { pattern } 3 \\
(n=41) \\
\end{array}$ & $\begin{array}{c}\text { Insufficient } \\
\text { information or } \\
\text { ambiguous } \\
\text { pattern } \\
(\mathrm{n}=149) \\
\end{array}$ \\
\hline Central injuries (head, neck, chest, abdomen) & 38 & 290 & 26 & 61 \\
\hline \multicolumn{5}{|l|}{ Upper limb: } \\
\hline Injuries & 98 & 219 & 20 & 57 \\
\hline Traumatic amputation & 5 & 5 & 33 & 12 \\
\hline \multicolumn{5}{|l|}{ Lower limb: } \\
\hline Injuries & 156 & 398 & 12 & 134 \\
\hline Traumatic amputation & 186 & 4 & 1 & 12 \\
\hline Genital injuries & 27 & 14 & 2 & 6 \\
\hline
\end{tabular}

TABLE $\mathrm{v}-U$ se of surgical and transfusion resources by patients injured by mines

\begin{tabular}{|c|c|c|c|c|}
\hline & $\begin{array}{c}\text { Injury } \\
\text { pattern } 1\end{array}$ & $\begin{array}{c}\text { Injury } \\
\text { pattern } 2\end{array}$ & $\begin{array}{c}\text { Injury } \\
\text { pattern } 3\end{array}$ & $\begin{array}{l}\text { Insufficient } \\
\text { information or } \\
\text { ambiguous } \\
\text { pattern }\end{array}$ \\
\hline $\begin{array}{l}\text { Mean No of operations/patient } \\
\text { No (\%) patients given blood transfusion } \\
\text { Mean No of blood units/patient }\end{array}$ & $\begin{array}{c}4 \cdot 6 \\
151(74) \\
4 \cdot 1\end{array}$ & $\begin{array}{c}2 \cdot 5 \\
51(14) \\
3 \cdot 8\end{array}$ & $\begin{array}{c}3 \cdot 0 \\
5(12) \\
3 \cdot 0\end{array}$ & $\begin{array}{c}2 \cdot 4 \\
23(15) \\
2 \cdot 1\end{array}$ \\
\hline
\end{tabular}

TABLE VI - Residual disability according to injury pattern

\begin{tabular}{|c|c|c|c|c|}
\hline & $\begin{array}{c}\text { Injury } \\
\text { pattern 1 } \\
(\mathbf{n}=201)\end{array}$ & $\begin{array}{c}\text { Injury } \\
\text { pattern } 2 \\
(\mathbf{n}=369) \\
\end{array}$ & $\begin{array}{c}\text { Injury } \\
\text { pattern } 3 \\
(n=41)\end{array}$ & $\begin{array}{c}\text { Insufficient } \\
\text { information or } \\
\text { ambiguous } \\
\text { pattern } \\
(n=149) \\
\end{array}$ \\
\hline $\begin{array}{l}\text { Upper limbs amputated } \\
\text { Hand } \\
\text { Forearm } \\
\text { Arm }\end{array}$ & 12 & 14 & $\begin{array}{r}25^{39} \\
13 \\
1\end{array}$ & 19 \\
\hline $\begin{array}{l}\text { Lower limbs amputated } \\
\text { Foot } \\
\text { Below knee amputation } \\
\text { Above knee amputation }\end{array}$ & $\begin{array}{c}7^{210} \\
149 \\
54\end{array}$ & $\begin{array}{r}3^{22} \\
13 \\
6\end{array}$ & 1 & 19 \\
\hline Other disability & 8 & 34 & 10 & 12 \\
\hline
\end{tabular}

amputations $) \div$ number of limb injuries. By this formula, $15 \%(210-186 \div 156)$ of the injured lower limbs of patients with pattern 1 injuries were eventually amputated; in patients with pattern 2 injuries $5 \%$ $(22-4 \div 398)$ of injured lower limbs were amputated; in patients with pattern 3 injuries $30 \%(39-33 \div 20)$ of injured upper limbs were amputated.

A total of 64 patients had other injuries: 59 had eye injuries with variable loss of vision; in patients with pattern 1 injuries one nerve palsy was recorded; in patients with pattern 2 injuries two nerve palsies and one urethral stricture were recorded and one patient was rendered deaf and blind.

\section{Discussion}

The study presented here relates to victims of antipersonnel mines admitted to ICRC hospitals. The long and difficult evacuation to these hospitals (most wounded arrived six hours or more after injury) means that those most seriously injured are not seen. This is verified by the low hospital mortality. The less seriously injured may not come to the hospital, making do with local treatment. It is known that the ICRC hospitals see only a small proportion of the injured from the conflicts in their regions. Information available in both locations is that there are many varieties of mines. The similar proportion of pattern 1 to pattern 2 injuries in each hospital would support this.

Civilians in both conflicts are at risk from these weapons, especially those with access to hospital B. It is particularly distressing that here, also, children seem to be susceptible, lending support to rumours that they may be used to walk ahead of combatants in areas where there is a risk of mines; other children may be tempted to pick up mines that have been dropped by air. It is possible that wounded non-combatants, especially women, are not as readily brought to first aid posts as wounded combatants.

\section{IMPLICATIONS OF INJURY PATTERNS}

The study confirms the observation that the patterns of mine injuries and their severity are related to the demand on surgical resources and the blood bank, and it provides a yardstick for any other medical staff whomanage or are planning to manage patients injured by mines. It affirms predictable disability from each $\stackrel{\text { क }}{\stackrel{5}{~}}$ pattern.

With a pattern 1 injury, in addition to receiving traumatic amputation of one foot or leg, the victim, if he or she survives, has a high chance of contralaterab lower limb injury and arm injury and a lower chance ofes genital and central injuries. The observation thatpattern 1 injuries are the most severe is confirmed by their being the greatest drain on surgical and transfusion resources. In pattern 1 there are more amputations, and lower limbs injured but not ampu-3 tated by the weapon have a higher chance of subse quent surgical amputation, with the result that the patient is usually a bilateral amputee. The largerio number of visits to the operating theatre made by thesepatients reflects difficulty in closing the amputations and in salvaging the other leg. This should be noted by surgeons unfamiliar with these injuries. The diffi- 0 culties of making the decision to amputate and the operations needed for correct amputation or limb salvage are persistently underestimated. A related observation in ICRC hospitals is that, of all patients those with limb injuries from mines use most blood.

In pattern 2 there is widespread injury from frag ments, with a predilection for the lower limbs. The injury is less severe than in pattern 1, as indicated by the smaller proportion of injured lower limbs requiring amputation. It is interesting that the higher proportion? of central injuries associated with pattern 2 does noß apparently increase the hospital mortality or blood use $\bar{\partial}$

The injury distribution in pattern 3 is entirely ing keeping with the history of handling a mine; no surprisingly, most patients require amputation of part or all the hand. Eye injuries were sustained in nearly की quarter of the patients ( 10 of 41 ).

Patients designated " $N$ " had a low number of operations and low blood consumption; this indicates that one reason for the poor documentation may be less severe injury. The number of upper and lower limbs amputations compared with those in patients with patterns 1,2 , and 3 injuries indicates that pattern contains a mixture of other patterns.

In pattern 1 and 3 injuries there is close contact between the limb and the device when it explodes은 Possible explanations for the difference in surgical demand between the two patterns are that amputation or salvage of the upper limb is technically easier; the mines that are handled may be smaller; a minqu triggered by a foot is buried and so the blast, directeo upwards, contains earth and grass; and the leg is more prone to an extreme compartment syndrome, which may be overlooked. ${ }^{3}$

\section{SURGERY AND DISABILITY}

It is known that severity of injury is only one factor determining the level of amputation. Others are thep delay in presentation, the judgment and capability of the surgeon, and the type of footwear worn by the victim. ${ }^{5}$ In ICRC hospitals the surgeons are encour aged to make every effort to maintain a tibial stump of acceptable length because this may be the factor that determines whether the patient can eventually work and therefore support his or her family.

In the hospitals involved in this study the only specialty emergency that is routinely referred to other agencies is penetrating eye injury. About $8 \%$ of 
patients have eye injury; there is no information about the number with permanently impaired vision. Our experience is that eye injury is sustained from fragments, mud, or sand thrown up by the explosion. Many victims lose one eye and have a variable degree of injury to the other; a minority are totally blinded.

The incidence of other disabilities in these patients is certainly higher than indicated here. Numerous nerve palsies are not documented, probably because they represent only one aspect of the successful salvage of a severely injured limb.

There is little information about the number of patients who discharged themselves from hospital. We are sure that this is quite a small number. The commonest reason for leaving hospital against medical advice is the cultural or religious unacceptability of amputation; some patients prefer to die. Had these patients remained in hospital there would have been a slightly higher number of eventual amputations.

This study focuses on the surgical aspects of antipersonnel mine injuries; one must bear in mind that the prospects for amputees in developing countries may be divorce, unemployment, or crime. The effect on the society of several thousand amputees may be considerable. The ICRC runs rehabilitation centres in many countries and worldwide produces 9000 prostheses a year, most of which are for victims of antipersonnel mines.

We thank Mr Heinz Weiler, Ms Ariane Curdy, and Ms Irene Deslarzes for their invaluable help with the database of this study.

1 Jones EL, Peters AF, Gasior RM. Early management of battle casualties in Vietnam. Arch Surg 1968:97:1-15.

2 Cheng XM, Lin YQ, Guo RF, Lian WK, Wang DT. Analysis of wound ballistics in 2414 cases of battle casualties. F Trauma 1990;6(suppl): 169-72. 3 Coupland RM. Amputation for antipersonnel mine injuries of the leg: preservation of the tibial stump using a medial gastrocnemius myoplasty. Ann R Coll Surg Engl 1989;71:405-8.

4 Adams DB, Schwab CW. Twenty one year experience with land mine injuries. f Trauma 1988;28(suppl):S159-62.

5 Traverso LW, Fleming A, Johnson DE, Wongrukmitr B. Combat casualties in northern Thailand: emphasis on land mine injuries and levels of amputation. Milit Med 1981;146:682-5.

(Accepted 26 September 1991)

\section{Dogs that bite}

\author{
P C Shewell, J D Nancarrow
}

\section{Abstract}

Objective-To study the circumstances of dog bites and identify risk factors.

Design-Postal questionnaire survey and case note review of victims of dog bites referred between 1982 and 1989.

Setting-One referral based regional plastic surgery unit.

Patients - 146 consecutive patients referred for TABLE I-Number of patients sustaining dog bites, according to age, September 1982-September 1989

\begin{tabular}{lr}
\hline Age (years) & No \\
\hline $0-$ & 25 \\
$5-$ & 30 \\
$10-$ & 24 \\
$15-$ & 10 \\
$20-$ & 5 \\
$25-$ & 6 \\
$30-$ & 1 \\
$35-$ & 13 \\
$40-$ & 5 \\
$45-$ & 5 \\
$50-$ & 7 \\
$55-$ & 5 \\
$60-$ & 2 \\
$65-$ & 3 \\
$70-$ & 3 \\
$75-$ & 2 \\
$\geqslant 80$ & 1 \\
\hline
\end{tabular}

West Midlands Regional Plastic and Jaw Surgery Unit, Wordsley Hospital, Wordsley, Stourbridge,

West Midlands

P C Shewell, FRCS, senior house officer

J D Nancarrow, FRCs, consultant plastic surgeon

Correspondence to Mr P C Shewell,

Royal Orthopaedic Hospital, The Woodlands, Northfield, Birmingham B31 2AP.

BMf 1991;303:1512-3 primary treatment of dog bites, for whom current addresses were available for $133,107(81 \%)$ of whom returned the questionnaire.

Results - The male to female ratio was $74: 72 ; 79$ (54\%) patients were aged below 15 years. The commonest dogs producing bites were Staffordshire bull terriers (15 cases), Jack Russell terriers (13), medium sized mongrels (10), and Alsatians (nine). 82 of $96(85 \%)$ dogs were male. 29 of $47(62 \%)$ adults were bitten at home and 45 of $60(75 \%)$ children at a friend's, neighbour's, or relative's house. 91 of 107 $(85 \%)$ bites occurred in the dog's home. Bites occurred during playing with $13(12 \%)$, petting 14 $(13 \%)$, or waking $16(15 \%)$ dogs. $45(42 \%)$ bites were judged as unprovoked. 32 bites were identified as severe and 11 attacks as sustained.

Conclusions-Most victims are bitten by male dogs which they either own or have had frequent contact with, and the bite occurs in the dog's home.

\section{Introduction}

The subject of dog bites has increasingly come to the forefront of public attention in recent months, generating much heated comment and opinion. We therefore decided to review patients with dog bites treated at the West Midlands Regional Plastic Surgery Unit to identify any risk factors associated with these injuries.

\section{Methods}

We examined the records of patients referred to the unit from September 1982 to September 1989 for treatment of dog bites and sent a questionnaire to each patient or to parents of patients aged under 15 years.
Questions concerned the place and circumstances of the bite, details of the dog, action taken, and the patient's (and parent's) subsequent attitude to the injuries and to dogs.

\section{Results}

Of 146 patients referred to the unit, all but three required out of hours surgery; the average length of stay was four days. No annual or seasonal variation in the number of bites was noted. The male to female ratio was $74: 72$ and $79(54 \%)$ were aged under 15 years (table I). The injuries consisted of 76 puncture wound and 304 lacerations, 81 of which involved loss of tissue. One hundred and twenty six $(86 \%)$ patients had injuries to their face or head.

Current addresses were available for 133 patients, and $107(81 \%)$ patients replied to the questionnaire Patients or their parents were asked to score both their injuries and the resultant scars; table II shows the replies. When asked about their present reaction to dogs $23(38 \%)$ children and nine (19\%) adults stated that they were nervous of dogs and $37(62 \%)$ children and $27(57 \%)$ adults that they were more cautious of them (average time from being bitten was $3 \cdot 4$ years).

TABLE II-Scoring of wounds and scars from dog bites in children and adults. Figures are numbers (percentages)

\begin{tabular}{lcclcr}
\hline & \multicolumn{2}{c}{ Wounds } & & \multicolumn{2}{c}{ Scars } \\
\cline { 2 - 3 } \cline { 5 - 6 } Severity & $\begin{array}{c}\text { Children } \\
(\mathbf{n}=59)\end{array}$ & $\begin{array}{c}\text { Adults } \\
(\mathbf{n}=47)\end{array}$ & & $\begin{array}{c}\text { Children } \\
(\mathbf{n}=59)\end{array}$ & $\begin{array}{c}\text { Adults } \\
(\mathbf{n}=47)\end{array}$ \\
\hline Minor & $2(3)$ & $8(17)$ & & $29(49)$ & $27(57)$ \\
Moderate & $22(37)$ & $20(43)$ & & $21(36)$ & $14(30)$ \\
Severe & $36(61)$ & $19(40)$ & & $10(17)$ & $6(13)$ \\
\hline
\end{tabular}

Figure 1 shows the breeds of dog responsible. When known, in 82 of $96(85 \%)$ bites the dogs were male and in 22 of $82(27 \%)$ they had had obedience training; in 36 of $53(68 \%)$ bites to children and 24 of $43(56 \%)$ bites to adults the dog was subsequently destroyed by the owners. Of 38 dogs subsequently kept by their owners, $7(18 \%)$ bit again.

Twenty nine $(62 \%)$ adults were bitten at home by 